\title{
Schedule of Responsibilities and the Assignment of Files at Civil Courts in Uganda
}

\author{
By Edrine Wanyama*
}

\begin{abstract}
This paper discusses the responsibilities, duties and function of judicial officers in Uganda, with a particular focus on civil actions. The paper in scope of judicial officers covers justices of the Supreme Court and the Court of Appeal. Judges of the High Court, registrars to the courts and magistrates of Magistrates courts. The paper in unpacking responsibilities of judicial officers focuses on civil matters. It briefly underscores that there is a difference between criminal and civil law. The paper emphasizes the need for administration of justice for all Ugandans at all times in a speedy manner. It further highlights the process of assigning files to judicial officers. It underscores that before assignment of files, proper procedure of filing civil suits including: instructions to counsel; choice of format of bringing action; payment of court fees; acquiring a number for the civil suit and holding a scheduling conference have to be done. It further highlights factors that may dictate assignment of files as including: pecuniary jurisdiction of the officer; undue influence and corruption; expertise of a judicial officer in a particular branch law; nature and size of workload; and the nature of the work a particular judicial officers is often engaged in. In assessing the findings, the paper identifies some of the challenges affecting the judiciary and performance of judicial responsibilities by judicial officers as including: lack of clear legal definition of responsibilities of registrars; corruption; technological gaps and challenges; limited human resources; failure to handle cases in the prescribed time; and finance and budget constraints. The paper concludes that judicial officers are charged with a primary duty of ensuring that they guard, protect and promote justice while keeping the judicial oath. The paper finally recommends: the need for clearly defined roles and responsibilities of registrars in the laws; adoption of key anti-corruption measures, taking service of court processes more seriously; and promoting access to information for knowledge increase on duties and obligations for the State and citizens in justice courses.
\end{abstract}

* Edrine Wanyama is a dual trained lawyer in Uganda and Tanzania. He holds a Master of Laws (LL.M) from the University of Dar es Salaam, a Bachelor of Laws Degree (LL.B) from Makerere University and a Diploma in Legal Practice (Dip L.P) from the Law Development Centre (Uganda). $\mathrm{He}$ is an advocate of the Courts of Judicature of the Republic of Uganda and has written and published widely in civil and political rights, economic, social and cultural rights, international law, environmental law and governance and oil and gas law governance. He can be contacted on edrinewanyama@gmail.com Mob: +256(0)782058298,+256(0)702058298. 


\section{A. Introduction}

Uganda" Court system is broadly divided into Criminal and civil. They are referred to as the Courts of Judicature. The courts of judicature are provided for by Chapter eight of the Constitution of the Republic of Uganda, 1995 (Constitution). Chapter eight of the Constitution is centered on the administration of justice in Uganda. To that effect, the Constitution provides that "Judicial power is derived from the people and shall be exercised by the courts established under this Constitution in the name of the people and in conformity with law and with the values, norms and aspirations of the people. "1 It is further provided that in adjudicating cases of both a civil and criminal nature, the courts shall apply: equality and non-discrimination, timely delivery of justice, adequate compensation to victims, promotion of reconciliation of parties and that justice shall be administered without undue regard to technicalities. ${ }^{2}$

The judiciary is further expected to be independent and free from any external influence or control when exercising its power. ${ }^{3}$ To ease the roles of justice dispensation by the judiciary, justice is administered through the courts of judicature. The courts of judicature include the; Supreme Court, Court of Appeal which also sits as the Constitutional Court, High Court; and such subordinate courts as Parliament may by law establish, including qadhis courts for marriage, divorce, inheritance of property and guardianship, as may be prescribed by Parliament in that order of hierarchy from the highest to the lowest. ${ }^{4}$ In line with the above, Uganda has inter alia put in place Magistrates Courts (Chief Magistrates, Magistrate Grade I and Magistrate Grade II Courts) and Local Council Courts. The category of other courts and tribunals include though not limited to; Tax Appeals tribunals, Industrial Court, Court Martial, Police Disciplinary Court, Electricity Tribunals and the Communication Tribunal. It is important to note that tribunals and disciplinary courts primarily deal with disputes and are usually constituted when disputes arise and require adjudication.

It is important to note that the broad categorization of courts in Uganda is into civil and criminal. However, there are instances where courts are separated as between the military and civilians. Hence, the Uganda Peoples' Defence Forces is governed by an Act of Parliament. The Uganda Peoples' Defence Forces Act establishes a General Court Martial which handles criminal matters in which soldiers are involved.The separation between military and civilian courts leads Uganda to another categorization of the Court system into civilian and military courts. This means that all courts civil and criminal, handling justice dispensation of ordinary citizens are referred to as civilian courts while those handling criminal actions and omissions of soldiers are referred to as military courts.

1 Article 126 (1), Constitution of the Republic of Uganda, 1995.

2 Constitution of the Republic of Uganda, 1995, note 1, article 126 (2).

3 Constitution of the Republic of Uganda, 1995, note 1, article 128.

4 Constitution of the Republic of Uganda, 1995, note 1, article 129. 
For the purpose of this paper, focus will be on the Courts of judicature which have been categorized above as the Supreme Court, Court of Appeal, High Court and other subordinate Courts. The paper will specifically focus on civil matters and the schedule of responsibilities and the assignment of files in Uganda. The paper will in terms of scope discuss the schedule of responsibilities of judicial officers as well as the assignment of files in civil courts. Among the key officers to be discussed include Judtices, Judges, Registrars and Magistrates.

\section{B. Mandate of Uganda's Judiciary}

In light of article 126 of the Constitution, the judiciary is primarily charged with ensuring that justice is served for all. In so doing, it must, as priority, strive towards independence, competence, trustworthiness and accountability. ${ }^{5}$ In so doing, the judiciary is guided by a number of objectives and functions. The objectives include: doing justice to all irrespective of their social or economic status; timely delivery of justice; award of adequate compensation to victims of wrongs; reconciliation of parties to suits; administration of justice without undue regard to technicalities and ensuring independence from any external controls or directions of individuals or authorities. ${ }^{6}$ Functions on the other hand include: Administering justice through resolving disputes between individuals, and between the State and individuals; Interpreting the Constitution and the laws of Uganda; Promoting the rule of law and contributing to the maintenance of order in society; Safeguarding the Constitution and upholding democratic principles; and Protecting human rights of individuals. ${ }^{7}$ In so doing, the judiciary is guided by the principles of: independence and impartiality, transparency, professionalism, integrity, accountability, equality and respect. ${ }^{8}$ It is important to observe that the above are a measure of the performance of the judiciary. Judicial officers thus, in performance of their functions, must strive towards attaining minimal standards of the above stated objectives and functions.

\section{Dispensation of Justice in Civil Courts}

The Uganda Constitution among others provides under article 20 for respect of rights and freedoms of the individual. The rights and freedoms of the individual or groups are inherent and shall be respected, upheld and promoted by all organs and agencies of government and by all persons. Inter alia, the organs and agencies mentioned include the judiciary which is part of the three arms of government. The three arms of government include the; Parliament, Executive and the Judiciary. Article 21 of the Constitution further provides for equa-

5 The Judiciary, “About the Judiciary.” Available at http://www.judiciary.go.ug/data/smenu/86//About \%20the\%20Judiciary.html (accessed August 19, 2016).

6 The Judiciary, note 5.

7 The Judiciary, note 5.

8 The Judiciary, note 5. 
lity of all persons, "... before and under the law in all spheres of political, economic, social and cultural life and in every other respect and shall enjoy equal protection of the law." The above provisions clearly show that all organs must respect and uphold all the rights of Ugandans. Additionally, there should not be any preferential treatment of any Ugandan when before the law. Rather, all Ugandans must be accorded due equality. Equality has to stand out in the exercise of duties and responsibilities by judicial officers. Justice dispensation is further found in article 28 of the Constitution which provides for the right to fair trial including a fair, speedy and public hearing before an independent and impartial court or tribunal established by law. To affirm the need for free, fair and speedy justice dispensation in Uganda's Courts, article 126 (2) (e) is to the effect that, “...substantive justice shall be administered without undue regard to technicalities".

Besides the Constitution, there are laws that govern civil justice in Uganda. These include the: Judicature Act Chapter 13 as amended by The Judicature (Amendment) Act, 2002, Civil Procedure Act Chapter 71 and the Rules there under and the Magistrate Courts Act Chapter 16 as amended by the Magistrate Courts (Amendment) Act, 2007. The other guiding rules include the; Judicature (Supreme Court Rules) Directions Statutory Instrument 13-11, Judicature (Court of Appeal Rules) Directions Statutory Instrument 13-10, Judicature (Commercial Court Division) (Mediation) Rules, 2007, Judicature (Mediation) Rules, 2013 and the Judicature (Court Bailiffs) Rules Statutory Instrument 13-16.

The above point to the justice dispensation in as far as they provide for the establishment of offices of judicial officers and stipulate the rules governing the justice processes from filling the case to execution. They also point out the different duties and responsibilities of judicial officers as will be shown in the discussion below.

\section{Officers of the Courts}

Officers of the Courts are categorized according to the different court. Their duties vary in accordance with hierarchy. Those who handle matters of adjudication include; justices, judges, chief registrars, registrars, deputy registrars, assistant registrars and magistrates. These officers are traceable in Chapter Eight of the Uganda Constitution and the Judicature Act under section 43 (1). Briefly; the Supreme Court consists of the Chief Justice and a minimum of six other justices. ${ }^{10}$ The Court of Appeal consists of a Deputy Chief Justice and a minimum of seven other justices. ${ }^{11}$ The Constitutional Court which handles matters regarding the interpretation of the Constitution is comprised by five justices whenever in sitting. ${ }^{12}$ It is important to note that it is the Court of Appeal that sits as the constitutional

9 Constitution of the Republic of Uganda, note 1, article 21 (1).

10 Constitution of the Republic of Uganda, note 1, article 130 (a) and (b).

11 Constitution of the Republic of Uganda, note 1, article 134 (1) (a) and (b).

12 Constitution of the Republic of Uganda, note 1, article 137 (2). 
court. ${ }^{13}$ The High Court is headed by the Principal Judge and has no specified maximum number of judges but has a minimum of twenty five (25) judges. ${ }^{14}$ It is that important to note that the High Court is spread across the Country. ${ }^{15}$ Registrars are provided for under article 145 of the Constitution. As such, the judiciary has the office of the Chief Registrar and other registrars as the parliament prescribes by law. ${ }^{16}$ Magistrates on the other hand are provides for by the Magistrates Courts Act as amended. Magistrates are categorized in; chief magistrate, magistrate grade I and magistrate grade II. ${ }^{17}$ There is no maximum limit on the number of Magistrates that may be appointed and posted across the country.

Worthy of note is that "the Chief Justice, the Deputy Chief Justice, the Principal Judge, a justice of the Supreme Court, a justice of Appeal and a judge of the High Court shall be appointed by the President acting on the advice of the Judicial Service Commission and with the approval of Parliament."18

\section{Duties and Responsibility of Judicial Officers}

It is important to note that the responsibilities of judicial officers above mentioned vary though with similarity in certain aspects especially in regard to registrars. The difference arises in from hierarchy and jurisdiction of each court. Jurisdiction in this case is both criminal and civil. In this particular discussion however, focus will be on civil jurisdiction. It is also important to note that the responsibilities of judicial officers at lower courts differ from those of higher Courts which usually handle appeals, save for the Constitution Court that handles matters of constitutional interpretation. Difference might also arise in matters of appeal from the Constitutional Court to the Supreme Court. Below is a highlight of the different responsibilities in the courts in Uganda.

\section{The Chief Justice}

The Chef Justice heads the judiciary and is responsible for the administration and supervision of all courts in Uganda and may issue orders and directions to the courts necessary for the proper and efficient administration of justice. ${ }^{19}$ The Chief Justice is also oversees the administration of other courts that do not necessarily fall from an administrative within the

13 Constitution of the Republic of Uganda, note 1, article 137 (1).

14 Constitution of the Republic of Uganda, note 1, article 138 (1) (a) and (b); see also the Judicature Act Chapter 13, section 13 (a) and (b).

15 Constitution of the Republic of Uganda, note 1, article 138 (2).

16 Constitution of the Republic of Uganda, note 1, article 146 (1).

17 Section 4 of the Magistrate Courts Act Chapter 16 as amended by the Magistrate Courts (Amendment) Act, 2007.

18 Constitution of the Republic of Uganda, note 1, article 142 (1).

19 Constitution of the Republic of Uganda, note 1, article 133. 
Judiciary. ${ }^{20}$ It is also important to note that the Chief justice also takes leadership of the Supreme Court Bench and usually gives the leading judgment in cases (presidential election petitions) and appeals from the Court of Appeal and the Constitutional Court. ${ }^{21}$ It should also be observed that he takes precedence over all justices of the Court of Appeal and judges of the High Court. ${ }^{22}$ The Chief Justice further has the powers, in consultation with the Deputy Chief Justice to create divisions of the Court Appeal. ${ }^{23} \mathrm{He}$ also appoints places in which the High Court may sit. In so doing, he or she aims at fulfilling the duty of ensuring that the High Court is accessible to all the people. ${ }^{24}$ The Chief Justice also chairs the Rules Committee established by section 40 of the Judicature Act. The Rules Committee makes "...rules for regulating the practice and procedure of the Supreme Court, the Court of Appeal and the High Court of Uganda and for all other courts in Uganda subordinate to the High Court." 25 Finally, the Chief justice makes rules of the Court relating to prerogative orders which may be issued by the court including inter alia, procedures and fees payable on documents filed or issued in cases where an order of mandamus, prohibition or certiorari is sought, the requirement for leave before making some applications and "requiring that where leave is obtained, no relief shall be granted and no ground relied upon, except with the leave of the court, other than the relief and grounds specified when the application for leave was made. "26 Finally, the Chief Justice according to section 44 of the Judicature Act is responsible for the custodianship of the seal of the Supreme Court. The Chief Justice may also assign the custody of the Supreme Court seal to the Deputy Chief Justice or a justice of the Supreme Court and may dictate or give directions on the manner in which the seal should be kept. ${ }^{27}$

Conclusively, the Chief Justice heads the judiciary and is responsible for efficient and speedy delivery of justice to all Uganda's citizenry. ${ }^{28}$ Above him there is no other in the judiciary. His duties are mainly administrative in nature, though he attends to cases that come on appeal to the Supreme Court and those that are only filed to the Supreme Court. So far in Uganda, it is only presidential election petitions that are originally filed in Uganda's Highest Court.

20 The Judiciary, “Administrative Structure”, http://www.judiciary.go.ug/data/smenu/90//Administrat ive\%20Structure.html (accessed August 8, 2016).

21 Section 2 (a) of the Judicature Act Chapter 13.

22 Judicature Act, note 21.

23 Constitution of the Republic of Uganda, note 1, article 135 (3).

24 Constitution of the Republic of Uganda, note 1, article 138 (2); see also Judicature Act, note 21, section 19.

25 Judicature Act, note 21, section 41 (1).

26 Judicature Act, note 21, section 42.

27 Judicature Act, note 21, section 44.

28 The Republic of Uganda, "Judiciary Staff Handbook”, First Edition, (Kampala, 2006) p.68. 


\section{The Deputy Chief Justice}

The Deputy Chief Justice is the head of the Court of Appeal and presides over this Court. ${ }^{29}$ The responsibilities include deputizing the Chief Justice as and when the need arises and heading the Court of Appeal and assisting the Chief Justice in the administration of the Court of Appeal. ${ }^{30}$ The Deputy Chief justice is also to perform functions assigned to him or her by the Chief Justice. ${ }^{31}$ Where the office of the office of the Chief Justice is vacant or where the Chief Justice is unable to perform his duties, the Deputy Chief Justice performs his or her functions until he or she resumes office. ${ }^{32}$ Notably, the Deputy Chief Justice leads the Bench whenever, the Court of Appeal sits to hear appeals and constitutional matters. The Deputy Chief Justice according to section 2 (a) of the Judicature Act takes precedence immediately after the Chief Justice. The Deputy Chief Justice also sits on the Rules Committee. ${ }^{33}$ Finally, the Deputy Chief Justice is responsible for the storage of the Court of Appeal seal. ${ }^{34}$

\section{The Principle Judge}

The Principal Judge is the head of the High Court and in that capacity, assists the Chief Justice in the administration of the High Court and subordinate courts. ${ }^{35} \mathrm{He}$ or she further performs other functions delegated or assigned to him or her by the Chief Justice. ${ }^{36}$ It also important to note that the principal judge is third most important person in the judiciary. He or she takes precedence immediately after the Deputy Chief Justice. ${ }^{37}$ According to section 19 , the principal judge together, in consultation by the Chief Justice can designate High Court Circuits for trial of both civil and criminal matters. Further, distribution of business before the High Court among the judges is a responsibility of the Principal Judge. ${ }^{38}$ It is also important to note that custodianship of the High Court seal is a duty of the principal judge. In furtherance of this duty, the Principal Judge may assign the custody of the High Court seal or a duplicate of it to a judge of the High Court and may specify the manner in which the seal should be kept and used. ${ }^{39}$

29 Constitution of the Republic of Uganda, note 1, article 135; see also section 9 of the Judicature Act.

30 Constitution of the Republic of Uganda, note 1, article 136.

31 Constitution of the Republic of Uganda, note 30.

32 Constitution of the Republic of Uganda, note 1, article 133 (2).

33 Judicature Act, note, 21, section 40.

34 Judicature Act, note, 21, section 44 (4).

35 Constitution of the Republic of Uganda, note 1, article 141.

36 Constitution of the Republic of Uganda, note 1, article 141.

37 Judicature Act, note, 21, section 2 (a).

38 Judicature Act, note, 21, section 20 (1).

39 Judicature Act, note, 21, section 44 (5) (a) and (b). 


\section{Justices of the Supreme Court and the Court of Appeal}

Other than the Chief Justice and the Deputy Chief Justice, the justices of the Supreme Court and the Court of Appeal as well as the Constitutional Court play a critical role in the administration of justice in Uganda through execution of their administrative and judicial duties, responsibilities and functions. Firstly, they play the role of constituting the Bench. ${ }^{40}$ Further, where the office of the Deputy Chief Justice is vacant; the Deputy Chief Justice is acting as Chief Justice; or the Deputy Chief Justice is for any reason unable to perform the functions of his or her office, the functions shall be performed by a justice of the Supreme Court or a justice of Appeal designated by the President, after consultation with the Chief Justice, or the acting Chief Justice, as the case may be until such person has been appointed to occupy the said position. ${ }^{41}$ It is also important to note that in performance of functions, the justices of the Supreme Court take precedence immediately after the Principal Judge. ${ }^{42}$ Further, the justices of the Court of Appeal take precedence immediately after the justices of the Supreme Court. ${ }^{43}$ It is important to observe here that a single justice of the Supreme Court may exercise any power vested in the Supreme Court in any interlocutory cause or matter before the Supreme Court and, a dissatisfied person with a decision of such justice may appeal that the matter be heard by a bench of three justices of the Supreme Court which may confirm, vary or reverse the decision. ${ }^{44}$ Likewise, a single justice of the Court of Appeal may exercise any power vested in the Court of Appeal in any interlocutory cause or matter before the Court of Appeal, and, a dissatisfied person with a decision of such justice may appeal that the matter be heard by a bench of three justices of the Court of Appeal which may confirm, vary or reverse the decision. ${ }^{45}$

\section{Judges of the High Court}

Away from the Principal Judge, Judges of the High Court play a critical role in the administration of justice especially through adjudication of civil and criminal matters. The High Court has unlimited original jurisdiction in all matters and may therefore be a court of first instance in any matter. Further, where the office of the Principal Judge is vacant; or the Principal Judge is for any reason unable to perform the functions of his or her office, the functions shall be performed by a judge of the High Court designated by the President, after consultation with the Chief Justice until such person has been appointed to occupy the said

40 Constitution of the Republic of Uganda, note 1, article 130 (b) on Justices of the Supreme Court, article 134 (b) on Justices of the Court of Appeal; see also the Judicature Act, supra note 14, section 3 (a) and (b) and section 9 (a) and (b) respectively.

41 Ibid article $136(2)$.

42 Judicature Act, note, 21, section 2 (b).

43 Judicature Act, note, 21, section 2 (c).

44 Judicature Act, note, 21, section 8.

45 Judicature Act, note, 21, section 12. 
position. ${ }^{46}$ Similar in the manner of ranking of hierarchy of justices of the Supreme Court and the Court of Appeal, judges of the High Court take precedence immediately after the justices of the Court of Appeal when in performance of functions. ${ }^{47}$ It is worth noting that judges are spread across the country and in so doing ensure fast and timely administration of justice. ${ }^{48}$ To validate the fast administration of justice, a single judge is mandated to hear and dispose of matters before him or her. ${ }^{49}$ Judges in dispensing justice may also sit in chambers and may make orders relating to costs. ${ }^{50}$ Nevertheless, orders made in Chambers other than those related to costs, may upon notice be set aside or discharged by the judge sitting in court. ${ }^{51}$

\section{Registrars}

The duties and responsibilities or registrars are categorized into judicial and administrative. In terms of similarity or difference, they are similar but with unique differences that make duties of one registrar different from the other. Sometimes, differences arise from the hierarchy of the court in which a particular registrar is deployed or occupying. Below are the general duties and responsibilities of registrars.

The Civil Procedure Rules Statutory Instrument 71-1 list the general powers of registrars under Order L (50). These powers include general powers inferred on registrars by law provisions for officers appointed by court. ${ }^{52}$ The officers referred to may be registrars. ${ }^{53}$ Registrars also have the power to handle all the formal steps preliminary to the trial, and all interlocutory applications. ${ }^{54}$ Further, registrars have the powers to issue formal orders for attachment and sale of property and for the issue of notices to show cause on applications for arrest and imprisonment in execution of a decree of the High Court. ${ }^{55}$ To ensure effectiveness in the administration of justice and running of the judicial offices, registrars are also charged with undertakings, inspections and ensuring that proceedings in court are carried out in accordance with the directions of the judge of the High Court or a commissioner appointed to examine and adjust accounts. ${ }^{56}$ It is also important to note that under Order L

46 Constitution of the Republic of Uganda, note 1, article 141 (2).

47 Judicature Act, note, 21, section 2 (d).

48 Judicature Act, note, 21, section 18 and section 19.

49 Judicature Act, note, 21, section 20 (2).

50 Judicature Act, note, 21, section 21 (1) and (2).

51 Judicature Act, note, 50.

52 Order L rule 1, Civil Procedure Rules Statutory Instrument 71-1.

53 Civil Procedure Rules, note, 52.

54 Civil Procedure Rules, note, 52, rule 3. It is important to note that under Order XXI rule 2 (3) registrars also have a responsibility of pronouncing judgments written and signed by a judge of the High Court when so directed.

55 Civil Procedure Rules, note, 52, rule 4.

56 Civil Procedure Rules, note, 52, rule 5. 
(50) rules 1, 2, 3 and 4, registrars are deemed to be a civil court and therefore, can handle all matters falling within the four rules of order $\mathrm{L}$ above. ${ }^{57} \mathrm{It}$ is further important to note that when a matter is brought before a registrar and the registrar finds it critical for High Court adjudication, “... the registrar may refer the matter to the High Court and a judge of the High Court may either dispose of the matter or refer it back to the registrar with such directions as he or she may think fit." ${ }^{58}$ This is express and as such, a registrar has the power to refer a matter brought before him to the High Court and the High Court may refer it back to the registrar to handle the matter and dispense with it. Finally, as a general duty of registrars, they are required to register all orders and judgments and are accordingly required to keep record of all proceedings and to have custody and keep proper account of all fees and fines payable or paid into court and all monies paid into or out of court. ${ }^{59}$ They may also be required from time to time to submit their accounts to the Auditor General for auditing and are to further pay the Secretary to the Treasury the amount of fines, fees and other monies in his or her custody at such intervals as the Secretary to the Treasury may direct. ${ }^{60}$

It is worth noting that under Oder V (5) on the issue and service of summons, rule 28 (a) on service in any foreign country is to the effect that, "Where leave is given to serve notice of the summons in any foreign country to which this rule may by order of the Chief Justice from time to time be applied, the following procedure...", shall inter alia be adopted: the notice to be served together with a copy of it translated into the language of the country in which service is to be effected, with a request for the further transmission of the notice through the proper channels to the government of the country in which leave to serve notice of the summons has been given, shall be sealed with the seal of the High Court for use out of the jurisdiction, and shall be forwarded by the registrar to the Minister together with, and with a request for the further transmission of the notice through the proper channels to the government of the country in which leave to serve notice of the summons has been given. The key responsibility of the registrar here is to ensure that the summons are transmitted from the High Court to the responsible Minister. The Registrar is also charged with the duty of receiving a copy of the service of summons and the costs involved are to be submitted to the Chief registrar of the High Court. ${ }^{61}$ Thus, he or she is to ensure that Foreign Service is effectively done.

The powers and functions of the registrars above are mainly aimed at ensuring fast and timely delivery of justice to Ugandans. It is also one way of ensuring that matters that would not necessitate appearing before the High Court are handled swiftly. Likewise, matters that would require High Court intervention should be easily referred to the High Court

57 Civil Procedure Rules, note, 52, rule 6.

58 Civil Procedure Rules, note, 52, rule 7.

59 Civil Procedure Rules, note, 52, rule 9.

60 Civil Procedure Rules, note, 52, rule 9.

61 Civil Procedure Rules, note, 52, Oder V rule 30 (c) and (d). 
for purposes ensuring transparency as well as the intervention of judges who are more senior to the registrars. Generally, the primary aim is to ensure that justice is swiftly served.

Despite the above powers, there are administrative duties and responsibilities which are primarily derived from a practical perspective. These duties and responsibilities include:

\section{a) Registrar Supreme Court}

The Judicial duties and responsibilities of the registrar Supreme Court include, handling taxation of bills of costs matters, Proof reading court proceedings before scheduling files for hearing, delivering of Judgments and Rulings as well as attending court sessions. The administrative functions of the Supreme Court registrar on the other hand include: Issuing court processes such as the issuance of summons, production warrants and hearing notices to parties; ${ }^{62}$ management of financial and human resources in the court; handling of complaints from other judicial officers, justices as well as the complaints from the general public; maintenance, replacement, increase through purchase and repair of court infrastructure; preparation of reports on progress and performance of the Court; promoting customer care to citizens coming to interface with the court and ensuring effective communication between the court and the public as well as ensuring effective and efficient service delivery to the citizenry; and ensuring that outreach and sensitization of the court and its work is effectively done amongst the citizens.

\section{b) Registrar Court of Appeal}

The registrar of the Court of Appeal also performs both judicial and administrative functions. The Judicial responsibilities include: handling taxation of bills of costs; proof reading court proceedings and signing certificates of correctness of the records before forwarding them to Supreme Court; delivery of rulings and judgments as indicated in the general powers of registrars above and attending court sessions. On the other hand, the administrative responsibilities of the registrar of the Court of Appeal include; issuing Court processes, that is, summons, production warrants and hearing notices, management of financial and human resources, handling of complaints brought before the court, maintenance of Court infrastructure, preparation of reports on performance and progress of the court, promotion of customer care, communication and service delivery and to conduct outreach and sensitization.

\section{c) Registrar High Court}

The registrar of the High Court among others is mandated to perform the following; running the High Court through his deputies and assistants and therefore ensures efficiency of

62 See for instance Order XXXVIII rule 10 on the setting of hearing dates by registrars. 
the court. He or she is also the secretary to the case backlog and case backlog reduction committees. He or she also: supervises all High Court deputy registrars, manages court bailiffs affairs to ensure that they conduct their business in accordance with the law and also stands in for the chief registrar when he is away on other duties or when he or she cannot be in position to perform his or her duties at a given time.

\section{d) Other Registrars / Deputy Registrars}

Other registrars and deputy registrars have both judicial and administrative responsibilities. The judicial responsibilities include: coordination of daily Court sessions, and ensuring timely production and availability of certified court proceedings including issuing Certificates of correctness of the records; issuing court process such as summons, production warrants and hearings notices; extracting and signing High Court orders and decrees; hearing some uncontested applications such as the release of passports where they have been confiscated or captured by authorities; and adjourning cases and setting dates for the next hearing. The administrative responsibilities include: issuing court process such as summons, production warrants and hearing notices; management of financial and human resources; handling of complaints; maintenance of court infrastructure; preparation of reports; promoting customer care, communication and service delivery; and outreach and sensitization.

\section{e) Deputy Registrar Executions}

This position is uniquely created for the High Court circuits in Kampala-Uganda's capital for executions. It is important to note here that executions happen in all High Court circuits across the country. However, this position is special and is referred to as a special Registry for several reasons. In terms of the judicial responsibilities, the deputy registrar executions hears applications for execution and all matters incidental thereto. Administratively, the following responsibilities accrue to the deputy registrar executions: management of court bailiffs, writing reports, proper management of the registry, ensuring communication to Court users through Court user committee meetings, maintenance of court infrastructure, ensuring that compilation of accurate case returns is accurate and ensuring effective service of court processes.

\section{f) Registrar for Magistrates Affairs and Data Management}

The registrar for magistrates' affairs and data management is primarily responsible for the coordination of all the affairs and the welfare concerning magistrates in the judiciary. Ideally, the registrar magistrates' affairs is charged with coordination of collection and analysis of the court case reports on adjudication of cases from magistrates and as well filing monthly progress reports on work and performance of magistrates to the Chief Registrar. He or 
she is also the link between the chief registrar and the magistrates. He or she is also to fasttrack the performance management function of the magistrates and file reports on a quarterly basis to the Chief Registrar on the performance of Magistrates. He is further mandated to develop training, coaching, mentoring and promotion plan for specific magistrates, including induction of new recruits into the office of magistrates.

On top of the above, the following are the responsibilities and functions of the registrar for magistrates. He or she is expected to perform the following: coordination of collection of monthly data from all Magistrate Courts in relation to case disposal and magistrates' needs with the view of facilitating management decisions; with support from the technical advisor to the judiciary, he or she is to carry out an annual strength, weaknesses, opportunities and threats analysis on the performance of the Magistrates' Courts and advise the Chief Registrar on the necessary measures to revamp and rejuvenate the magistrates' output and image amongst the public; in light of advise, he or she is mandated to make recommendation and follow up on disciplinary action for indisciplined magistrates; holding regular regional meetings with Magistrates on matters that affect the effective and timely delivery in adjudication of cases; in consultation with the Chief Registrar, conduct on-spot checks on the Magistrates Courts with a view of quality assurance and offer hands-on support; developing of pocket handbooks relating to delivery of justice for magistrates; and to perform any other task assigned by the Chief Registrar within the workings of the judiciary.

\section{Magistrates}

Magistrates are primarily governed by Magistrates Courts Act. They are also recognized under the Judicature Act as, officers whose decisions are appealable from lower to higher courts in an ascending order of hierarchy. ${ }^{63}$ Magistrates are graded into three. That is, chief magistrate; magistrate grade I; and magistrate grade II. ${ }^{64}$ It should be noted that in terms of civil jurisdiction or the pecuniary jurisdiction magistrates shall handle the following matters: chief magistrate handles matters where the value in dispute does not exceed fifty million shillings (about \$15151.5); magistrate grade I handles matters where the value in dispute does not exceed twenty million shillings (about \$6060.6); and magistrate grade II handles matters where the value in dispute does not exceed five hundred thousand shillings (about \$151.5). Nevertheless, their functions are similar and can be seen in the following ways.

63 See for instance, the Judicature Act, note, 21, sections, 6 on appeals to the Supreme Court in civil matters; section 16 on appellate jurisdiction of the High Court; section 17 on supervision of magistrates courts; section 41 (2) (r) on the functions of the Rules Committee.

64 Magistrate Courts Act, note 17, section 4. 


\section{a) Chief Magistrates}

Chief magistrates are inter alia expected to carry out the following responsibilities: timely disposal of 600 cases per annum; supervision of magistrates Grade I and II and making reports on their supervision and performance; reporting on at least a minimum of ten of the District Coordinating Committee (DCCS); ${ }^{65}$ reporting and report compilation on observance of human rights issues arising out of visiting places of incarceration within their magisterial area for both criminal and civil matters; filling of monthly cases and financial returns as well as timely submission of monthly management reports; ensuring that the values of the judiciary are upheld by the staff through submission of monthly meetings; supervision and reporting on Local Council Courts Execution Orders; ${ }^{66}$ submission, on a quarterly basis of performance reports of non-judicial officers; and managing the inventory of for judiciary assets.

65 DCCs are part of the JLOS District Chain Linked Committees and play an important role in overseeing and coordinating reform programmes. DCCs are aimed at improving the administration of justice and maintenance of law and order. Oversee and coordinate improvements in the administration of justice and maintenance of law and order. DCCs are aimed at enhancing case management and reducing case backlog; Addressing issues relating to the JLOS focus areas of Land Justice, Commercial Justice, Criminal Justice and Family Justice; Conducting district level monitoring of JLOS activities and inspect or visit offices of JLOS agencies; Acting as focal point for JLOS district activities; undertaking civic, public education and outreach programmes; Ironing out misunderstandings between stakeholders; Creating an open and safe environment in which it is possible to discuss each stakeholders performance, strength and weaknesses; Undertaking periodic reporting to the JLOS Technical committee through the JLOS Secretariat with copy of the report to the committee patron who is the resident Judge of the High Court circuit; Striving to remove impediments in the chain of justice; Organizing JLOS open days in the areas of their jurisdiction; and Ensuring that all institutions respect, observe and promote the bill of rights in the Constitution with regard to timely delivery of justice, fair trial rights, rights of suspects and persons in detention. http://www.judiciary.go.ug/files/downloads/THE\%20ROLE\%20OF\%20MAGISTRATES\%20IN \%20THE\%20MANAGEMENT\%20OF\%20DISTRICT\%20CHAIN\%20LINKED\%20COMMITT EES\%20(DCC)\%20AND\%20CASE\%20BACKLOG\%20CLEARANCE.pdf (accessed August 16, 2016).

66 Local Council Courts are established by the Local Council Courts Act, 2006. According to section 3 of the Act, they are village, parish, town, division and sub-county based. In terms of compositions, section 4 of the Act provides that; the local council court of a town, division or sub-county consist of five members appointed by the town council, division council or sub-county council on the recommendation of the respective executive committee. At least two members of the town, division or sub-county local council are supposed to be women. Membership to the court does not require any academic qualifications. Under section 5 of the Act, one only needs to be a resident of the area of jurisdiction of the council for which the court is appointed, be of high moral character, knowledgeable in the common local language of the community in question, not be a member of a local council, a member of Parliament or a member of a statutory body and not be a member of another local council court. The nature and manner of composition of the Court poses a number of challenges in operation and assurance that justice will be served. 
b) Magistrate in Charge of Stations

Magistrate Grade 1 in charge of stations is not in any way special or particularized position in Magistrates Courts. In some circumstances, it may not be practical to have efficient supervision by the Chief Magistrate over the magistrates courts placed under him. Sometimes it is a result of long distances between the main magisterial area and the location of the Court. The Magistrate Grade 1 in charge may then be in charge of a given area, hence being addressed as magistrate in charge of stations. He or she performs the following functions; Timely disposal of 400 cases per annum; supervising, writing and compiling on reports on the performance of Magistrates Grade II and non-judicial staff under their jurisdiction; writing and compiling minutes of at least ten DCC meetings per annum; filling of monthly cases and financial returns as well as timely submission of monthly management reports; write reports or minutes on the one open day meeting per annum; ensuring that the values of the judiciary are upheld by the staff through submission of monthly meetings; and managing the inventory of for judiciary assets.

\section{c) Magistrates Grade I}

The Magistrates Grade I performs the following responsibilities; he or she must dispose of 280 cases per annum in a timely manner; make monthly reports on the supervision and performance of Magistrates Grade II and non-judicial staff under their jurisdiction; writing and compiling minutes of at least ten DCC meetings per annum; filling of monthly cases and financial returns as well as timely submission of monthly management reports; write reports or minutes on the one open day meeting per annum; and managing the inventory of for judiciary assets.

\section{d) Magistrates Grade II}

The Magistrates Grade II is responsible, among others for; timely disposal of 250 cases per annum; making of monthly reports on the supervision and performance of non-judicial staff under their jurisdiction; reporting on at least ten DCC meetings per annum; filling of monthly cases and financial returns as well as timely submission of monthly management reports; writing reports or minutes on the one open day meeting per annum, supervising and reporting on the performance of Local Council Courts; and managing the inventory of for judiciary assets.

\section{Other judicial Officers}

There are other officers in the judiciary who play a critical role in administration of justice. They fall quite far from those who adjudicate matters but in one way or another, their work impacts on the mandate of the judiciary. These officers' responsibilities are unique and noteworthy. 
a) The legal secretary for Chief Justice, Deputy Chief Justice and Principal Judge

The private Legal Secretary to the Chief Justice, Deputy Chief Justice and Principal Judge performs the following duties and responsibilities. He or she: acts as a private legal secretary and in-charge of administration in the chief justice's or the deputy chief justice's or the principal judge's office; carries out legal research, attends sessions and manages complaints; coordinates official visits, appointments and travels; manage resources in the Chief Justice's or the Deputy Chief Justice's or the Principal Judge's office; maintains an up to date chart of case statistics from all high Court Circuits (this though applies only to the Personal Legal Secretary to the Principal Judge); and performs any other task assigned by the Chief Justice or the Deputy Chief Justice or the Principal Judge office.

\section{b) Deputy Registrar in Charge of Research and Training}

The purpose of the office of the deputy registrar in charge of research and training is to inter alia strengthen the judiciary, promote innovation and improve functionality and proficiency of the judiciary. The deputy registrar in this office is charged with the following duties: Initiating research portfolio for Management's approval; maintenance of an efficient research registry; undertaking and informing research activities of the judiciary; supervising and mentoring the research team at the Judicial Studies Institute; preparation of research reports and other publications of research activities; supervision of the law reporting function; and coordination of the research component of all the training modules approved by the Judicial Studies Institute.

\section{c) Research Officer Judicial Studies Institute}

The research officer Judicial Studies Institute deputizes the deputy registrar in charge of research and training. He or she is in charge of initiating preparation and development of the Judicial Studies Institute Law Journal; making proposals for review of the training curriculum guided by the Judiciary transformational needs; developing an impact-tracking mechanism on the training workshops of the Judicial Studies Institute and performing other responsibilities as assigned from time to time by the immediate supervisor.

\section{d) Law Reporting Officer in Charge of Uganda Legal Information Institute}

Law reporting officer in charge of Uganda Legal Information Institute is responsible for: managing the Uganda Legal Information Institute (ULII) at the Judicial Studies Institute; Uploading all approved processed reading materials on ULII website portal; attending to calls and information requests for the uploaded reading materials on ULII and other related research legal materials that can be availed by the Judicial Studies Institute; creating and maintaining linkages on the communication of new precedents of legal jurisprudence and decisions on crosscutting Justice Law and Order Sector (JLOS) wider judicial management 
issues; and performance of other responsibilities as may be assigned from time to time by the immediate supervisor.

\section{e) Law Reporting Officer in Charge of Law Reports}

Law reporting officer in charge of law reports deputizes the law reporting officer in charge of ULII. He or she is also charged with the responsibilities of: managing the documentation center at Judicial Studies Institute; developing information, education and communication materials as identified and forwarded to the directorate of research at the Judicial Studies Institute within the wider JLOS Institutions; identifying court decisions for the digests for the law reporting database; preparing and seeking approval of the Judicial Studies Institute Law Reports and case digests and information, education and communication materials leaflets for dissemination to the wider JLOS Institutions; and performance of any other responsibilities as may be assigned by the immediate supervisor from time to time.

It is important to note that the above officers, that is, Justices, judges, registrars and magistrates are mandated to perform duties that facilitate justice processes. Effective and efficient performance of the officers means service of people's justice needs in a free, fair and timely manner. It also means that justice will be served without undue regard to technicalities. Equally, the above positions form the foundation for which the judiciary, its mandate, objectives and functions are built. It follows further that, where the officers of the court discussed above inefficiently perform, the purpose of the judiciary is lost, for a shortfall in one of them might likewise affect the performance of the other. Conclusively, the above positions together with the officers in occupation are important for an efficient justice system in Uganda. And in so doing, they must work interdependently.

\section{Assignment of Files}

The process of assigning files to judicial officers is a process that starts at a dispute that may arise between parties, and therefore requiring court intervention for an amicable conclusion. Thus far, before files are assigned, there must be a dispute warranting court intervention, instructions are then given to council and the due court processes kick start. In the discussion below is a highlight of the different processes leading to assignment of files in Uganda's courts to judicial officers.

\section{Giving instructions to counsel}

Where dispute arises, negotiations are usually triggered between affected parties. Where negotiations fail, one party may commence proceedings against the other party. Commencement of proceedings is usually through counsel who receives instructions from the party who wished to pursue Court remedies. It is important to note that aggrieved parties are usually advised to take on civil proceedings in court as a last resort. This is because civil 
proceedings are lengthy and therefore waste a lot of time. Time wastage is made worse by bureaucracies in the justice processes. Additionally, civil proceedings are expensive and may attract undesirable costs and embarrassment especially in the circumstances where a party who has taken the case to Court loses the matter. Normally, the aggrieved parties are advised to pursue other simpler and easier avenues before thinking of Court. Hence parties are usually advised to write a letter to the party acting in breach or who has already committed a breach or whose omission causes alarm and a need for civil action. The letter is usually a demand notice which is also called the notice of intention to sue from the prospective plaintiff to the prospective defendant asking that the prospective defendant stops the breach forth with or rights the wrong. Where these efforts fail, then the aggrieved party is free to seek justice from the courts. Notwithstanding the above, an aggrieved party is free to approach court for remedies. The above are usually done through counsel for the aggrieved party.

\section{Filing}

At the filing of the suit, counsel for the prospective plaintiff must pay attention to the facts presented before him or her and establish whether they raise triable issues, identify the court with the appropriate jurisdiction for the matter, firmly establish whether the prospective plaintiff has the locus standi and also establish the right prospective defendant in the proposed suit or action. It is important to note that counsel for the prospective plaintiff must serve a notice of intention to sue to the prospective defendant lest the plaintiff loses out on the costs of the suit. ${ }^{67}$ The suit filing may take any of the following formats; ordinary suit which is made in a plaint or statement of claim; originating summons in which evidence is by affidavit; ${ }^{68}$ Notice of motion, mainly used for interlocutory applications; ${ }^{69}$ and petition or chamber summons mainly used for company matters and family and domestic relations proceedings like divorce and succession. The case is then registered, fees are also paid and the cases is allocated a number which then is then forwarded to the registrar or the chief magistrate for consideration. There are other processes such as the service of summons and hearing notices, submission of a written statement of defence within 30 days for individuals and 45 days for government by the prospective defendant.

It is important to note that before a file is assigned to a judicial officer, a scheduling conference and in some cases, arbitration and conciliation is held. ${ }^{70}$ Where the aforementio-

67 Rule 39 of the Advocates (Remuneration and Taxation of Costs) Rules SI 267-4.

68 Civil Procedure Rules, note 52, Order 34.

69 Magistrate Courts Act, note 17, Order 52 rule 1.

70 Arbitration is found in Order XLVII (47) which is to the effect that; rule 1, "Where in any suit all the parties interested who are not under disability agree that any matter in difference between them in the suit shall be referred to arbitration, they may, at any time before judgment is pronounced, apply to the court for an order of reference." Rule 2, "the arbitrator shall be appointed in such manner as may be agreed upon between the parties." These provisions are based on mutual respect 
ned fail, the file is then assigned to a judicial officer. According to Order XII (12) of the civil Procedure Rules, court shall hold a scheduling conference to sort out points of agreement and disagreement, the possibility of mediation, arbitration and any other form of settlement. This procedure usually arises after filing of the last reply from the other party (defendant) and after interlocutory applications have been filed. The period is usually within twenty eight days from the date when the last reply or rejoinder was filed in the court. In Uganda, a scheduling conference is now mandatory for every civil action. ${ }^{71}$ The scheduling conference ideally works to ensure that the dispute after scheduling progresses as expedi-

as well as the interest or the parties. Court may according to rule 5 appoint an arbitrator where the parties have failed to agree on one. The Arbitration and Conciliation Act Chapter 4 of the Law of Uganda is premised on procedures and behaviour of conciliators or arbitrators in domestic arbitration and international arbitration. It can be said that the Act was primarily aimed at ensuring and enhancing the autonomy of parties to a particular bargain that could have led to the dispute sought to be sorted or resolved through reconciliation or arbitration. As a major step towards promoting autonomy of parties, a Centre for Arbitration and Dispute Resolution is established by section 67 of the Arbitration and Conciliation Act whose functions under section 68 include: (a) to perform the functions referred to in sections $11,12,13,14,15$ and 51 ; (b) to perform the functions specified in the UNCITRAL Arbitration Rules of 1976; (c) to make appropriate rules, administrative procedure and forms for effective performance of the arbitration, conciliation or alternative dispute resolution process; (d) to establish and enforce a code of ethics for arbitrators, conciliators, neutrals and experts; (e) to qualify and accredit arbitrators, conciliators and experts; (f) to provide administrative services and other technical services in aid of arbitration, conciliation and alternative dispute resolution; (g) to establish appropriate qualifications for institutions, bodies and persons eligible for appointment; (h) to establish a comprehensive roster of competent and qualified arbitrators, conciliators and experts; (i) to facilitate certification, registration and authentication of arbitration awards and conciliation settlements; (j) to establish and administer a schedule of fees for arbitrators; (k) to avail skills, training and promote the use of alternative dispute resolution methods for stakeholders; (1) to do all other acts as are required, necessary or conducive to the proper implementation of the objectives of the Act. It should be noted that before a case is referred for arbitration, certain conditions must be fulfilled. These have been laid down in Shell (U) Ltd vs Agip (U) Ltd Supreme Court Civil Appeal No.49/1995. The conditions are: 1. There is a valid agreement to have the dispute concerned settled by arbitration. 2. Proceedings in Court have been commenced. 3 . The proceedings have been commenced by a party to the agreement against another party to the agreement. 4 . The proceedings are in respect of a dispute so agreed to be referred. 5. The application is made after appearance by the party to the proceedings. 6 . The application is made after appearance by that party, and before he has delivered any pleadings or taken any other "step in the proceedings." 7. The party applying for stay and is ready and is willing do all things necessary to the proper conduct of the arbitration.

71 This position has been validated by Tororo Cement Co. Ltd V Frokina International Ltd S.C.C.A. No. 2 of 2001. In this case, court gave justifications for a scheduling conference and hence; "The principal objective of the scheduling conference is to enable court to assist parties to dispose of cases expeditiously by sorting out points of agreement and disagreement or assessing the possibility of mediation, arbitration and other forms of settling the suit. After a scheduling Conference, and where it is necessary, interlocutory applications can then be made and be disposed of before the suit is fixed for hearing. In that way the progress of the suit is managed systematically. In this case, it is my view that the point raised by the present proceedings should have been properly raised and dealt with during a scheduling conference or soon thereafter. One hopes that the holding of scheduling conference will be a regular feature in the trial of civil cases by all trial courts.". 
tiously and economically as possible to a fair settlement by negotiation or mediations or some other system of civil litigation. During the scheduling, only triable issues are kept, some hopeless cases are solved summarily, parties are advised on the most appropriate form of dispute, co-operation between the parties is promoted, time tables and control of progress for the case is fixed and the likely benefits and costs of the case are considered and appropriate advise given to the parties. It should be noted here that the court may exercise its powers to extend or shorten the time for compliance with any rule practice direction of the court. It may also adjourn or set a specific date for hearing, or it may stay any proceedings generally or decide the order in which the issues are to be tried when the case comes up for hearing.

It is important to note that arbitration and conciliation most often take course when the matter has already been set for hearing in the court or is actually in the process of being heard. At any given time, they may ask that their matter be referred to an arbitrator. A scheduling conference however, takes place before the matter is set for hearing.

\section{Assigning the Files}

Upon successful scheduling conference in civil matters between parties to a dispute and their counsel, the matter is set down for hearing. It should be noted that before the actual hearing date, files are signed to a particular judicial officer. Such judicial officer usually hears that particular case from the beginning to setting down of the judgment. The process of assigning files, usually by registrars is usually dependent on a number of factors.

\section{Pecuniary Jurisdiction}

Though usually determined at the beginning of the suit, and usually a duty of counsel to determine forum of the case, registrars usually assign files based on pecuniary jurisdiction. For instance, in magistrates courts, matters where the value in dispute does not exceed fifty million shillings (about \$15151.5) are assigned to the chief magistrate; matters where the value in dispute does not exceed twenty million shillings (about \$6060.6) are assigned to the magistrate grade I while matters where the value in dispute does not exceed five hundred thousand shillings (about \$151.5). are assigned to the magistrate grade II. Likewise, the High Court has unlimited original jurisdiction and any civil matter of any pecuniary value may be referred to the High Court. ${ }^{72}$ Nevertheless, for matters of practice and easy adjudication of matters as well reducing case backlog and not bogging down the work of the High Court only civil matters of a value exceeding fifty million shillings (about \$15151.5) are referred to the High Court. This principal also caters for hierarchy of courts and eases choice of fora.

72 Constitution of the Republic of Uganda, supra note 1, article 139 (1); see also Judicature Act, note 21, section 14 (1). 


\section{Undue Influence}

In an interview with three advocates, undue influence partly determines which judge at the level of the High Court or magistrate at the magistrates' courts receives which file. Undue influence is usually on request by the advocate or it may be through corruption. One advocates states that; "It is easy to tell the registrar that this is the judge I would like to have handle my case and the registrar will. It is so easy and formalities are not strictly followed." 73 In another interview on the manner of assignment of files, an advocates said; "Assignment of files is sometimes dependent on choice of the judicial officer. Those who are hated at the court by those who assign files have very few files for either being complicated or hard to convince into corruption. Those who are flexible tend to have many case files."74 In another phone interview with and advocate of the Courts of Judicature, he stated that; we lawyers have a way we influence registrars to assign our files to judges of our interest." 75

From the above findings, it is quite clear that while there are formal procedures and requirements for assignment of files, taking to consideration, the work load and other factors. Assignment of files is also determined by undue influence and corrupt practices. Such manner of assignment process has an impact on the justice processes and renders the process flawed.

\section{Expertise in a given Branch of Law}

The expertise of a judicial officer in a particular field usually attracts files usually in their line of expertise. For instance, a judicial officer who is experienced or with a special skill in a particular line of law will receive files in line with their expertise. For instance, in magistrates' courts, the chief magistrate considers expertise in issues such as family and land before he or she assigns a file to a magistrate. Likewise, the commercial division of the High Court handles commercial transactions. Not any judge can handle any issue. Thus far, experience and expertise determines which judicial officer receives which file.

\section{Work Load}

The workload at all levels specifically magistrates' courts and High Court has an impact on the manner of assignment of files. "At the level of magistrates' courts, the chief magistrate usually looks at the workload before he assigns files. Magistrates with few files are usually assigned more files while those with many files may not receive until those in their possession have reduced." 76 The consideration of workload usually applies across all the courts

73 Interview on August 4, 2016 at 15:30 hours at Makerere University School of Law.

74 Interview with a civil society activist and Advocate of Courts of Judicature of the Republic of Uganda on August 02, 2016 at 17:03 hours in Jinja district.

75 Phone interview with an advocate on August 16, 2016 at 21:09 hours while at Kampala.

76 Phone interview, note 75 . 
including the High Court. It is therefore important to observe that the less or heavier the workload is for a judicial officer will determine how many files such officer receives and, in so doing, the registrar or chief magistrate looks at the factor of lighter load, more files of new cases and heavy load, less files or new cases.

\section{Execution}

Matters of execution are often handled by registrars. All files on execution are therefore usually forwarded to registrars. In so doing, they work together with Court Bailiffs who are appointed by the registrar. Usually, a judgment debtor is served the decree, a certificate of taxation and the taxed bill of costs and a demand for payment. The judgment debtor is indebted to the judgement creditor and failure to pay attracts application for an execution decree by the judgment creditor. It is the mandate of the registrar to issue a warrant of execution to enable recovery by the judgment creditor.

\section{E. Challenges Encountered in Civil Justice Processes}

There is no clear definition of the positions of the Chief Registrar and a registrar under the Laws of Uganda. The Constitution does not spell out their functions like it does for the counter parts, that is, justices and judges. This makes it difficult for them to operate as they are not fully aware or sure of their roles and privileges.

Corruption is a major challenge in the judiciary. Citizens continue to be deprived of justice because of corruption. There is no such thing as free and fair justice. Those who are economically empowered by their way to desired outcomes of cases before courts, to which they are party while the poor remain at no mercy.

There are technological challenges within the judiciary. Challenges range from limited technological equipment especially computers to their usage. Until judicial officers cope with the fast advancing technology, information and records management in Uganda's judiciary is still a major challenge.

The number of judicial officers is still small. This means a heavy backlog of cases. The capacity of individuals to handle matters before them is not proportionate to their load. There is too much to do and yet human resources are limited.

The judiciary is now highly politicized. Politicization has widely affected administration of justice contrary to what was envisaged in the Constitution. In fact judicial independency has been overly compromised. For instance, in August 10, 2016, a raid by a rowdy mob and goons on Makindye Chief Magistrate's Court in support of the Inspector General of Police-General Kale Kayihura disrupted court process. ${ }^{77}$

77 The Judiciary, "Raid on Court Unacceptable - Chief Justice", available at http://www.judiciary.go .ug/data/news/262/Raid\%20on\%20Court\%20Unacceptable\%20-\%20Chief\%20Justice.html (accessed August 19, 2016); Blanshe Musinguzi, "Raid on court unacceptable - Chief Justice", The Monitor, August 12 2016. Available at http://www.monitor.co.ug/News/National/Katureebe-co 
Delivery of justice is a challenge and there is little of cases that have been handled and completed in a timely manner. For instance, between July 2006 and June 2010 of the total civil cases filed, courts had completed 7,889 (83\%) within the stipulated period of 24 months while $1,571(17 \%)$ case files aged between 2 years to 20 years back. ${ }^{78}$

Finances and budget constraints continue to affect justice. For instance, delivery of summons has majorly been affected by lack of transport facilitation to process servers. Hence between July 2006 and June 2010, 43\% of failed deliveries of summons were attributed to lack of facilitation/transport. ${ }^{79}$ Equally, there is no money to purchase modern technological equipment for court effective processes.

\section{F. Conclusion}

Judges, Magistrates and other judicial officers are charged with a primary duty of ensuring that they guard, protect and promote justice. Judicial officers are hence expected to respect and uphold the laws of the land and their personal conduct is at all times expected to be

ndemns-pro-IGP-court-raid--/688334-3341362-item-01-3ipjfd/index.html (accessed August 19, 2016). Gen Kayihura was expected to appear in Makindye Chief Magistrate's Court on Wednesday August 10, 2016 to plead to torture charges that arose from the police's brutal beating of supporters of Opposition leader Dr. Kiiza Besigye in the previous month. The allegations are that; "Gen Kayihura and his fellow officers, being superior officers of the Uganda Police Force, in various places in and around Kampala, between 2011 and 2016 but most notably on July 13, and on July 14, are liable for the acts of torture committed against Mr. Joseph Kaddu, Mr. Andrew Ssebitosi, Mr. Rogers Ddiba, and other members of the general public, including boda boda riders and supporters of Dr Besigye. The brutality took place under the command of Mr Andrew Kaggwa, former Kampala Metropolitan South Regional Police commander. They encircled Dr Besigye's supporters at Busaabala Road junction off Entebbe Road and clobbered them."The Chief Justice likened the Wednesday events to the infamous 2005 attack on the High Court by heavily armed security operatives who besieged the temple of Justice. Reports further note that; "The armed Black Mamba operatives, as they are commonly known, raided court to re-arrest Dr Besigye, then FDC president, after he had been granted bail in a case where he was accused of treason as a purported leader of the shadowy People's Redemption Army. However, the Chief Justice was quick to draw lines between the two incidents; describing the one in 2005 as an "organized security raid" and the Wednesday one as a "mob raid." He said the raid on Makindye court points to a possible derailment. "If one side is going to organize mobs to prevent the courts from doing their job, to prevent lawyers from presenting the cases of their clients, then there is something fundamentally wrong and we must address it as a country and as citizens," Hon. Justice Katureebe noted." (The Judiciary, "Raid on Court Unacceptable - Chief Justice", available at http://www.judiciary.go.ug/d ata/news/262/Raid\%20on\%20Court\%20Unacceptable\%20-\%20Chief\%20Justice.html) (accessed August 19, 2016); Blanshe Musinguzi, "Raid on court unacceptable - Chief Justice", The Monitor, August 12 2016. Available at http://www.monitor.co.ug/News/National/Katureebe-condemns-pro-I GP-court-raid--/688334-3341362-item-01-3ipjfd/index.html (accessed August 19, 2016).

78 Office of the Auditor General, "Value For Money Audit Report On Disposing Of Cases In The Judiciary", (Kampala, 2011.).

79 Office of the Auditor General, note 78. 
beyond reproach. ${ }^{80}$ They do so by keeping with the judicial oath and performing their duties without fear or favour. ${ }^{81}$ In so doing, they are to ensure that justice is served in accordance with the Uganda Constitution and other laws at both the national and international level. They should accordingly front justice as a priority when in the exercise of their duties, opposed to individual or selfish interests. Indeed, the Code of Conduct for Judges, Magistrates and other Judicial Officers of 1989 for Uganda rightly summarizes their duties and responsibilities in Rule 8 . Rule 8 specifically states that;

"A Judge or Magistrate should dispose promptly of the business of the Court. However, in so doing he must ensure that justice is not only sure - but just. Protracted trials of a case must be avoided whenever possible. Where a judgement is reserved to be delivered on notice it should be delivered within the next 60 days, unless for good reason this is not possible."

\section{G. Recommendations}

The positions of Chief Registrar and a registrar need to be clearly defined under the law just like other judicial posts. Less of this does not assure proper and timely dispensation of justice as registrars tend to feel disgruntled.

Anti-corruption measures needed to be tightened in the judiciary. Tightening and narrowing the space through which corruption takes place will improve on justice processes and delivery and will ensure that the normal course of court business takes course, free from undue influence. Perhaps, salaries of judicial officers should be enhanced. This may reduce on cases of corruption. There should also be clear guidelines within the judiciary on corruption and the consequences corrupt tendencies attract.

The judiciary should take more serious, court processes such as service of summons to defendants. This will close the gap in justice delivery. Justice delivery will consequently improve as parties to cases will receive every information they need to enable them prepare appropriately for cases before court. Summons will be served in a timely manner, defences will be filed and scheduling conferences will yield desired results.

Technological measures aimed at enhancing justice should be promoted and implemented without delay. These measures should focus on total digitalization of the judiciary and court processes. This will mean electronic recording and presentation of evidence in courts, electronic filing of cases, digital case management, audio-visual presentation of evidence; and electronic data management in the judicial sector. ${ }^{82}$ Success of these measures will en-

80 Rule 1, The Code of Conduct for Judges, Magistrates and other Judicial Officers of 1989-Uganda. Available at http://www.deontologie-judiciaire.umontreal.ca/fr/magistrature/documents/CODE_U GANDA.pdf (accessed August 16, 2016).

81 Code of Conduct for Judges, Magistrates and other Judicial Officers, note 80.

82 Justice Bart M. Katureebe the Hon Chief Justice of Uganda, "Opening Remarks at the Stakeholders' Consultative Workshop on the Judiciary ICT Strategy FY2015/2016 - FY2019/2020 on June 
hance efficiency and effectiveness in judicial systems. ${ }^{83}$ It will also mean improved information and records management as well as easy retrieval of records whenever requested for by the public.

The judiciary should promote access to information if it is to progressively perform in an efficient manner. Access to information is power. It is a fundamental human right on which all other rights depend. Hence, there is need for judicial compliance with the Access to Information Act, 2005. Accordingly, the minister for justice and constitutional affairs needs to report to parliament on the status of access to information in the ministry. This will facilitate knowledge increase citizens will know their duties and obligations in as far as the pursuance and dispensation of justice are concerned.

\section{Bibliography}

Anthony Conrad K. Kakooza, "Abitration and Conciliation in Uganda: A Domestic Perspective" (Kampala, 2009)

Blanshe Musinguzi, "Raid on court unacceptable - Chief Justice", The Monitor, August 122016.

Henry Peter Adonyo, "Structure and Functions of the Judiciary", (Mukono, 2012).

JLOS, "A Citizen's Handbook on Law and Administration of Justice in Uganda", Third Edition, Judicial Service Commission (Kampala, 2007).

John Mary Mugisha, "The Role of the Advocate and the Litigant During Scheduling Conference" (Kampala, 2003)

Justice Bart M. Katureebe the Hon Chief Justice of Uganda, "Opening Remarks at the Stakeholders' Consultative Workshop on the Judiciary ICT Strategy FY2015/2016 - FY2019/2020 on June 7, 2016", (Kampala, 2016).

Office of the Auditor General, "Value for Money Audit Report on Disposing of Cases in the Judiciary", (Kampala, 2011)

Sam Rogers Wairagala, "The Role of Magistrates in the Chain Linked Committees (DCC) and Case Backlog Clearance", (Mukono, 2011).

The Republic of Uganda, “Judiciary Staff Handbook”, First Edition, (Kampala, 2006)

\section{Websites}

http://www.monitor.co.ug http://www.judiciary.go.ug/ http://www.deontologie

7, 2016", (Kampala, 2016). Available at http://www.judiciary.go.ug/files/downloads/Opening\%20 Remarks\%20by\%20the $\% 20 \mathrm{Hon} \% 20 \% 20 \mathrm{CJ} \% 20 \mathrm{ICT} 1$.pdf.

83 Katureebe, note 82. 